\title{
Research on Levying Carbon Tax in China
}

\author{
Fangwen $\mathrm{Yang}^{\mathrm{a}}$ and $\mathrm{Ye} \mathrm{He} \mathrm{e}^{\mathrm{b}}$ \\ School of North China Electric Power University, Baoding071000, China \\ ayfwyfw@126.com, b2398415412@qq.com \\ *The corresponding author
}

\section{Keywords: Carbon tax; Carbon dioxide emissions}

\begin{abstract}
Global warming is one of the most important problems around the word which every country has to confront. Carbon tax is one of the common economic means used to solve environmental problems in recent years. Against this background, low carbon economy treat realizing low energy, low emission, low pollution as the goal of economic form, which quickly gained the recognition around the world, and will put it into practice. The introduction of carbon tax is one of the most powerful policy tools for controlling carbon dioxide emissions. On the one hand, it can relieve the pressure on the domestic resources and environment, change the way of promoting economic development, and guide the economy to the low carbon development reasonably. On the other hand, it will help to perfect our country's resources and environment tax system, improve the tax system of green degree. Through tax levers, we can coordinate the relationship between the economic development and environmental protection. From the perspective of the combination of theory and reality, this paper analyzes the necessity and feasibility of the introduction of a carbon tax in our country, puts forward the basic goals and principles of the introduction of a carbon tax in China. From the perspective of factors such as tax system, initial design the basic content of the carbon tax system, and put forward the concrete implementation frameworks, including carbon tax and related taxes function orientation, the introduction of a carbon tax implementation roadmap in our country, as well as relevant supporting measures are suggested.
\end{abstract}

\section{Introduction}

Carbon Tax and Its Related Concepts. Carbon tax, which is levied on carbon dioxide emissions .Specifically, carbon tax is to reduce carbon dioxide emissions, for the purpose of the fossil fuels (such as coal, natural gas, gasoline and diesel oil, etc.) according to the carbon content levy a tax or carbon emissions.

The Theoretical Basis of a Carbon Tax. There are two theories about the introduction of carbon tax. The one is the polluter pays principle (PPP principle). "Polluter pays principle" is proposed to solve the problem of the environment responsibility of polluters, namely who should shoulder the external environment cost. Emitter of carbon dioxide obtain their own interests and benefits ,but they increase the social cost, they inevitably should take responsibility for their own behavior, the responsibility should measure for the damage of degree of hazard is most scientific and reasonable, taxing carbon tax according to the emissions of carbon dioxide, completely accords with the principle of for their own behavior to undertake corresponding obligations. The another is the public product theory. The environment is a kind of public goods with non-competitive and non-exclusive. At present, With the accelerating speed of environmental degradation in our country, environmental governance costs more and more, Environmental degradation to a certain extent has the irreversibility. So we can't go in the way of treatment after pollution. Government provides the money of the public service suitable for survival and living environment from government revenues, a carbon tax amount of tax revenue can not only reduce the energy cost but also provide the government with the environment public products.

The Necessity of China's Carbon Tax Analysis. I intend to talk about the necessity of levying a carbon tax from the following three aspects. First of all, the introduction of carbon tax can reduce domestic ecological environment pressure. Affected by the distribution of the energy constraints, 
our country is one of the few in the world to one of the coal as main energy consumer, in order to realize the sustainable development of economy and environment, the government has put the energy conservation and emissions reduction as the focus of current work. Carbon tax as a means of powerful policy to achieve energy conservation and emissions reduction, which should become one of the main policy tools in China's response to climate change. Secondly, the introduction of carbon tax is helpful to establish the international image of responsible. Although, China don't have the obligation to reduce emission, But as the world's largest carbon dioxide emissions, the pressure of Limits and emission reduction become more and more. So, China should levy carbon tax. Not only accord to the trend of the development of international environmental policy, but also can improve the international image of itself and to gain the initiative in future negotiations. Finally, the introduction of carbon tax is the need of perfecting the environmental tax system. Through the introduction of a carbon tax, we can reduce other distorting tax, and realize the perfection of the whole tax structure and optimizing, we will adopt fiscal and taxation systems conducive to scientific development, further deepening the reform of tax system is of great significance.

The Feasibility Analysis of the Introduction of a Carbon Tax in Our Country. According to the policy and technology, our country have the feasibility of the introduction of a carbon tax. First, we can look at the policy of our country. Carbon tax not only conforms to our country scientific outlook on development, but also can achieve energy conservation emissions reduction targets, also it accords with the China national plan to address climate change demands to make effective policy mechanism, is the current response to climate change in China. Second, we have the mature technology. Technical feasibility. Compared with sulfur tax, waste water tax environment tax, carbon tax has the characteristics, such as, it's easy to measure, operate and detect.

If the carbon tax is implemented, it will produce some positive effects, such as reduce energy demand, raise the government revenue and reduce air pollution, etc.

\section{Discussion}

China's current carbon tax's scope and object can be identified as: In the production, management and other activities due to the consumption of fossil fuels directly to the natural environment emissions of $\mathrm{CO} 2$. Since $\mathrm{CO} 2$ is generated by the consumption of fossil fuels, the target for carbon tax will ultimately fall on fossil fuels such as coal, natural gas, refined oil, and so on. According to the carbon tax scope and object, China's carbon taxpayers can be identified as: units and individuals who directly let $\mathrm{CO} 2$ into the natural environment. It's acknowledged that there are two link in Carbon Tax 's taxation link. The first one is in Production processes, the Second one is in Consumption links. I mainly analyze the following two parts.

Tax Basis. The choice of tax basis. Theoretically, It's reasonable to let the actual Carbon Dioxide Emissions as the basis for taxation. However, it's difficult to monitor the Carbon Dioxide Emissions, and it's difficult to operate. In practice, we often use the estimated Carbon Dioxide Emissions as a tax basis.

Determination of estimated emissions. According to the IPCC Guidelines for National Greenhouse Gas Inventories, The calculation of Carbon Dioxide Emissions are listed:

\section{Carbon Dioxide Emissions=Fossil Fuel Consumption $\times$ Carbon Dioxide Emissions Coefficient.(1)}

Carbon Dioxide Emissions Coefficient=Calorie $\times$ Carbon Emissions Factor $\times$ Carbon Oxidation RatexCarbon Conversion Coefficient.

The fossil fuel consumption refers to the actual consumption of fossil fuels, which is generated by the production and operation of the enterprise. The Carbon Dioxide emission coefficient refers to the Carbon Dioxide Emissions per unit of fossil fuel. Low calorific value refers to the complete combustion of fossil fuels, the combustion of water vapor in the presence of gaseous heat, also known as net heat; carbon emission factor is the fossil fuel unit calorific value of carbon emissions; carbon oxidation rate is The rate of carbon oxidation, the ratio of carbon dioxide to carbon emissions; the carbon conversion coefficient is the conversion coefficient of carbon to carbon 
dioxide.

Tax Rates. The form of carbon tax is closely related to the tax basis, as we take Carbon Dioxide Emissions as the tax basis, enterprise should adopt the way of quantity-based collection, that is, the use of fixed-rate form. The following principles should be followed in designing the tax rate.

First, the tax rate should reflect the marginal cost of Carbon Dioxide Emissions. Second, Country should consider the influence of the macroeconomic and industrial competitiveness. In the end, the design of the tax rate level should take full account of the differential factors. Coal, natural gas and refined oil and other different fossil fuel should be taken different tax rates.

\section{Conclusion}

The Relationship Between Carbon Taxes and Other Taxes. In China's current tax system, the fossil fuels is not only taxed by carbon tax, but also by the resources tax, value-added tax and consumption tax and other taxes. there is a cross in the taxation about the carbon tax and other fossil fuels tax, so it is necessary to analyze the relationship among the carbon tax ,resource tax and consumption tax.

The Implementation of the Carbon Tax. In the international agreement, developing countries should assume the obligations of the global climate change. So our country should levy carbon tax, in order to reduce the resistance and the negative effects of carbon taxes implementation. Carbon tax also need to follow the gradual reform train of thought. Besides, government can adopt measures of gradually rising the tax rate. Because there are many factors, it is necessary to design the rout and process of the carbon tax implement, and they should according the actual national conditions of our country to design rout and process.

According to the analysis, levying carbon tax can not only reduce the Carbon dioxide emissions, but also affect the macroeconomic and micro-subjects, etc. Therefore, according all aspects of China's current external environment, levying carbon tax need to meet the following conditions: a good domestic macroeconomic environment, a good international economic environment and moderate tax burden level.

The choice of the Carbon tax implementation. According to the carbon or carbon emissions as the tax basis to levy tax. Through the Integration and optimization of the tax system, which is beneficial to strengthen the force of the incentive to carbon dioxide emissions and develop low-carbon economy.

The Corresponding Policies of the Carbon Tax. The government should do its utmost to publicize carbon tax. Besides, government should implement progressive strategies. From the foreign carbon tax implementation experience, the design of the carbon tax need to coordinate with other taxes. We can learn from them. While we levy a carbon tax, we can appropriately reduce individual income tax and enterprise income tax at the same time. We can do these to reduce the influence on social economy and maintain stability of the tax. In addition, the carbon tax is one of the means to reduce carbon dioxide emissions, which should match the national emission reduction incentive policy and new energy policy. the integrated use of economic means, administrative means, etc. At the same time, in order to guarantee the effective implementation of the tax, We can establish a evaluation feedback mechanism.

\section{References}

[1] Friedl B.M. Getnzer. Determinate of C02 emissions in a small open economy [J].Ecological Economy CS 2003 (45):133-148.

[2] Goulder L.H 1995: Environmental taxation and the double dividend: a reader's guide, International Tax and Public Finance, 2.

[3] Gilbert E. Metealf, 1999: Distributional Analysis of Green Tax Reform National Tax Journa1, 52. 
[4] Mikael Skou Andersen, Paul Ekins. Carbon-Energy Taxation: Lessons from Europe [ M] .New York: Oxford University Press,2010.

[5] M.X Zhang, CGE Simulation for Levying Carbon Tax in China and International Experience of Levying Carbon Tax[J].Chinese Journal of Population Resources and Environment,2011,9(2).

[6] S.R Zheng, A.H Luo, Hong Yao. Research on the Relation of Carbon Tax on Carbon Emission and Economic Development in China [J]. Advanced Materials Research 2013 2695(807).

[7] D.F Cai, Ting Xue. Drawing Lessons from Foreign Experiences and Levying Carbon Tax in China at the Proper Time [J]. Advanced Materials Research 2014 2915(869).

[8] Nordhaus,W. D ( 2007 ) . To tax or not to tax: Alternative approaches to slowing global warming. Review of Environmental Economies and Policy. 26-44.

[9] Lawrence H. Goulder. Carbon tax design and USindustry performance. Tax Policy and the Economy 1992 Volume6 59 104.

[10] Andrea Baranzini, Jose Goldemberg. A Future for Carbon Taxes [J].Ecological Economics2000, (32):402-412. 